УдК 330.3:338.2

\title{
ІНВЕСТИЦІЙНА ДІЯЛЬНІСТЬ ПІДПРИЄМСТВА: СТРАТЕГІЯ І ТАКТИКА УПРАВЛІННЯ
}

\section{INVESTMENT ACTIVITIES OF THE ENTERPRISE: MANAGEMENT STRATEGY AND TACTICS}

\author{
Галько Людмила Романівна \\ кандидат економічних наук, \\ Західноукраїнський національний університет \\ ORCID: https://orcid.org/0000-0001-6118-4243
}

\author{
Halko Liudmyla \\ West Ukrainian National University
}

\begin{abstract}
У статті досліджено взаємозв'язок між процесами стратегічного планування та оперативного супроводу реалізації інвестиційних рішень підприємства. Узагальнено цільові орієнтири стратегічного управління інвестиційною діяльністю та розглянуто особливості формування базових інвестиційних стратегій підприємства. Визначено складові тактичного управління інвестиційною діяльністю, які регламентують процедуру прийняття управлінських рішень (інвестиційна політика) та визначають кінцевий результат їх реалізації (інвестиційний портфель). Акцентовано, що збалансування складу інвестиційного портфелю відбувається в умовах наявних обмежень часу та бюджету при дотриманні вимог ліквідності та законодавчих регуляторних норм. Виділено напрямки оперативного управління інвестиційною діяльністю підприємства, узагальнено етапи реалізації відібраних інвестиційних проектів та підходи до реструктуризації складу фрінансових активів інвестиційного портфрелю підприємства.
\end{abstract}

Ключові слова: управління інвестиційною діяльністю, інвестиційна стратегія, інвестиційна політика, ліквідність активів, ризик та дохідність інвестицій, інвестиційний порторель, реальні та фрінансові інвестиції.

В статье исследована взаимосвязь между процессами стратегического планирования и оперативного сопровождения реализации инвестиционных решений предприятия. Обобщены целевые ориентиры стратегического управления инвестиционной деятельностью и рассмотрены особенности формирования базовых инвестиционных стратегий предприятия. Определены составляющие тактического управления инвестиционной деятельностью, регламентирующие процедуру принятия управленческих решений (инвестиционная политика) и определяющие конечный результат их реализации (инвестиционный портфель). Акцентировано, что сбалансирование состава инвестиционного портоеля происходит в условиях ограничений времени и бюджета при соблюдении требований ликвидности и законодательных регуляторных норм. Выделены направления оперативного управления инвестиционной деятельностью предприятия, обобщены этапы реализации отобранных инвестиционных проектов и подходы к реструктуризации состава фринансовых активов инвестиционного портореля.

Ключевые слова: управление инвестиционной деятельностью, инвестиционная стратегия, инвестиционная политика, ликвидность активов, риск и доходность инвестиций, инвестиционный портоель, реальные и финансовые инвестиции.

Making informed decisions requires mutual coordination of management actions according to the purposes, terms and methods at all stages of investment process. A comprehensive combination of strategic, tactical and operational tools of investment management ensures the timely achievement of set goals of the enterprise in specific investment conditions. The article is devoted to the study of relationship between processes of strategic planning and operational support for implementation of investment decisions of the enterprise. The variability of the modern business environment determines the necessity to apply a strategic approach to the organization of enterprise investment activities. The investment strategy is subject to corporate business strategy (increase, stabilization or reduction), which affects the content of investment decisions and the nature of investment. Thus, the enterprise can choose the strategy of investment support for accelerated growth, the strategy of investment support of limited growth or anti-crisis investment strategy. It stated that components of tactical investment management regulate the procedure for making management decisions (investment policy) and determine the final result of their implementation (investment portfolio). It is emphasized that balancing the composition of enterprise investment portfolio is carried out in 
the conditions of time and budget restrictions in compliance with liquidity requirements and legal regulations. Limited resources available for investment require setting priorities in capital allocation between potentially profitable assets. It is obvious that effective management of enterprise investment portfolio requires forming the target capital structure based on reaching a compromise between its risk and return. Operational investment management involves both implementing selected real investment projects and restructuring the composition of financial assets of enterprise investment portfolio. Systematic and consistent of strategic, tactical and operational management decisions of the enterprise provide current control over the implementation of its innovation initiatives in accordance with the chosen model of investment behavior. This approach to the organization of investment activities is designed to provide organic unity of the declared strategic goals, expected results and means of their achievement.

Keywords: investment management, investment strategy, investment policy, asset liquidity, risk and return of investment, investment portfolio, real and financial investments.

Постановка проблеми. Підприємство здійснює інвестиційну діяльність, виходячи із наявної потреби в рамках цільової орієнтації його бізнес-стратегії. Реалізуючи власну модель інвестиційної поведінки, підприємство не лише забезпечує срінансування потреб власної операційної діяльності та сприяє технологічному оновленню виробництва, але й підтримує платоспроможність та фрормує конкурентні переваги товаровиробника на ринку.

Прийняття управлінських рішень щодо доцільності розміщення інвестицій вимагає ретельного аналітичного обґрунтування. Вибір інвестиційно привабливих об'єктів узгоджується за цілями із прийнятою інвестиційною стратегією підприємства та перевіряється на відповідність вимогам інвестиційної політики щодо очікуваної дохідності, рівня ризику, термінів окупності вкладеного капіталу і необхідної ліквідності активів.

Оптимізація інвестиційних потреб підприємства і можливостей їх забезпечення досягається за рахунок виваженого управління інвестиційними процесами на основі поєднання стратегічного планування інвестиційної діяльності та тактичних засобів досягнення поставлених цілей в конкретних умовах інвестування.

Аналіз останніх досліджень і публікацій. Взаємозв'язок інвестицій із процесами економічного зростання та масштабування сучасного бізнесу обумовлює значний інтерес дослідників до питань організації інвестиційної діяльності на підприємстві. Ґрунтовні дослідження теоретичних положень та прикладних аспектів управління інвестиційними процесами на підприємствах проводилися такими вченими-економістами як І.О. Бланк, Л.Б. Бушовська, Г.Г. Гайдай, С.В. Глухова, Д.І. Голубєв, П.Л. Гринько, С.М. Дунайчук, Н.В. Замятіна, О.В. Когут, І.М. Крейдич, Т.В. Майорова, Л.С. Селіверстова, Л.С. Ситник, Т.О. Сімкова, Л.П. Скотнікова, І.В. Угрімова, О.О. Федоров, О.В. Феєр, А.В. Череп, М.В. Чорна, А.М. Ясир та ін. Критичний аналіз економічної літератури показав, що дослід- ження особливостей процесу прийняття інвестиційних рішень на підприємстві проводилися в розрізі окремих управлінських інструментів, а саме, фрормування інвестиційної стратегії, розробки есрективної інвестиційної політики, управління інвестиційним портсрелем, обґрунтування інвестиційних проєктів та програм.

Виділення невирішених раніше частин загальної проблеми. Прийняття обґрунтованих рішень потребує взаємного узгодження управлінських дій за цілями, термінами та методами виконання на усіх етапах інвестиційного процесу - від стратегічного планування до практичної реалізації проєктних робіт. 3 огляду на це, актуальним вектором наукових пошуків виступає розробка цілісної системи управління інвестиційною діяльністю підприємства, реалізація якої забезпечить чітку координацію інвестиційних рішень та взаємне узгодження напрямків і форм інвестування. Такий концепт управління інвестиційними процесами на підприємстві сприятиме своєчасному досягненню поставлених стратегічних цілей, враховуючи наявні бюджетні обмеження та допустимий рівень ризику.

Постановка завдання. Мета статті полягає у фрормуванні системного підходу до реалізації фрункціоналу інвестиційного менеджменту підприємства на основі органічного поєднання послідовності підготовки і виконання стратегічних, тактичних та оперативних рішень щодо практичного освоєння інвестицій.

Виклад основного матеріалу дослідження. Інвестиційна діяльність безпосередньо пов'язана із наявністю у підприємства певної сукупності переваг, які зумовлюють його інвестиційну привабливість, і визначається наявністю потенційних інвесторів, які мають бажання розмістити свій капітал, а також системою інструментів, що дають змогу цей капітал використовувати з максимальною есрективністю [1, с. 173].

Відповідно до логіки процесу інвестування можна виділити три взаємопов'язані рівні управління інвестиційною діяльністю підприємства: 
1 - стратегічний рівень (моделювання інвестиційної поведінки підприємства у довгостроковій перспективі, обґрунтування інвестиційних можливостей підприємства досягати поставлених стратегічних цілей);

2 - тактичний рівень (пошук та вибір інвестиційно привабливих активів, фрормування таргетованого інвестиційного портоелю підприємства за наявних бюджетних обмежень);

3 - оперативний рівень (реалізація окремих інвестиційних проєктів та реструктуризація портфрелю фрінансових інвестицій, забезпечення поточного контролю та оцінки ефрективності інвестиційних рішень).

Усі управлінські рішення, прийнятті в процесі інвестування, повинні бути пов'язані за часом і ресурсами, не суперечити один одному та розподілятися за конкретними відповідальними виконавцями [7, с. 86]. Система взаємозв'язків між елементами стратегічного, тактичного та оперативного управління інвестиційною діяльністю підприємства представлена на рис. 1.

Мінливість сучасного бізнес-середовища зумовлює необхідність застосування стратегічного підходу до організації інвестиційної діяльності підприємства. Важливість розробки інвестиційної стратегії пояснюється кардинальними змінами цілей операційної діяльності підприємства через появу нових можливостей для зростання бізнесу, що потребує відповідних змін товарного асорти-

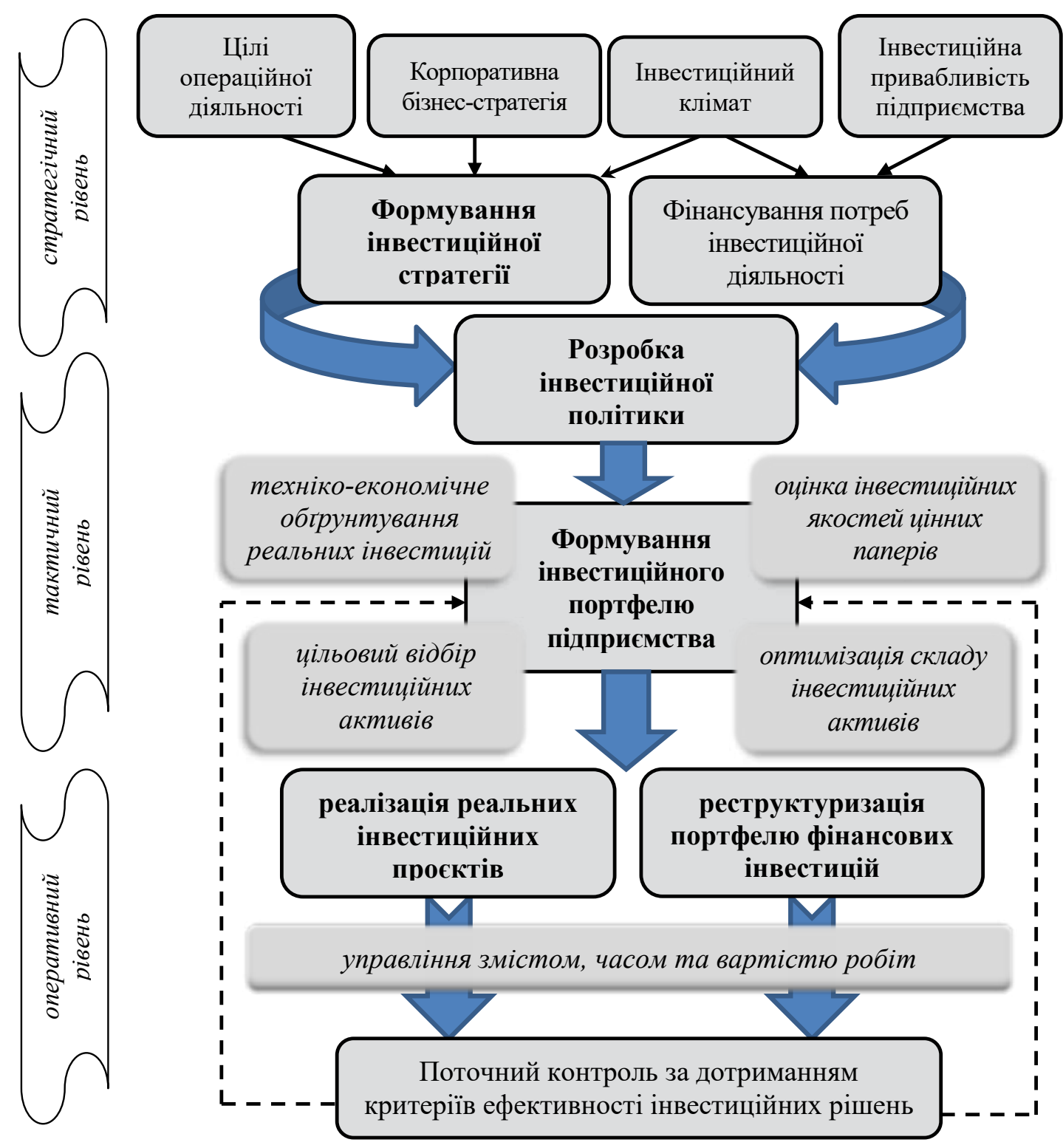

Рис. 1. Взаємозв'язок стратегічного, тактичного та оперативного управління інвестиційною діяльністю підприємства

Джерело: сфрормовано автором 
менту, впровадження нових технологій, освоєння нових ринків збуту та розширення цільових сегментів [10, с. 20].

В основі стратегічних інвестиційних рішень повинен лежати активний пошук альтернативних напрямів, фрорм і методів здійснення інвестиційної діяльності, обґрунтований вибір об'єктів інвестування та фрормування дієвих механізмів реалізації інвестиційної політики. Ефективність інвестиційного планування на окремих етапах розвитку підприємства кількісно виражається у максимізації ринкової вартості бізнесу, темпах економічного зростання, підвищення добробуту власників у поточному і майбутніх періодах.

Інвестиційна стратегія репрезентує систему довгострокових цілей інвестиційної діяльності підприємства, реалізація яких передбачає вибір найбільш вигідних шляхів розширення та оновлення активів 3 метою забезпечення основної спрямованості його економічного розвитку. Вона формує генеральну комплексну програму дій, яка визначає пріоритетні для підприємства напрями та фрорми інвестування, характер фоормування інвестиційних ресурсів, послідовність етапів реалізації довгострокових інвестиційних цілей, межі можливої інвестиційної активності підприємства, а також систему фрормалізованих критеріїв, за якими воно моделює, реалізує та оцінює свою інвестиційну діяльність [6, с. 21]. Отже, інвестиційна стратегія виступає концепцією, яка пов'язує і спрямовує розвиток інвестиційної діяльності підприємства.

Передумовою формування інвестиційної стратегії виступає загальна стратегія економічного розвитку підприємства. Відносно неї інвестиційна стратегія має підпорядкований характер і повинна узгоджуватися за цілями та етапами реалізації. В даному контексті інвестиційна стратегія розглядається як інструмент вдосконалення та підвищення есрективності поточної діяльності підприємства, а її масштаби визначають темпи його економічного зростання.

Таким чином, інвестиційна стратегія має враховувати особливості базових стратегій підприємства (зростання, стабілізації або скорочення), які й визначають ступінь інвестиційної активності підприємства. Стратегія інвестиційної підтримки прискореного росту підприємства спрямована на забезпечення високих темпів операційної діяльності і застосовується тоді, коли збільшення обсягів реалізації продукції вимагає відповідного приросту активів підприємства. Пріоритетним напрям- ком стратегічного інвестиційного розвитку підприємства при цьому виступає нарощення обсягів реального інвестування. Стратегія інвестиційного забезпечення обмеженого зростання передбачає збалансування інвестиційних потреб операційної діяльності та необхідного рівня фрінансової безпеки підприємства. У цьому випадку заплановані стратегічні зміни у складі порторелю інвестицій $€$ мінімальними, а приріст активів відбувається із врахуванням рівнем ризику. Антикризова інвестиційна стратегія призначена забезпечити фрінансову стабілізацію підприємства у процесі виходу з кризи. Особливо важливим напрямком управління за такої моделі стратегічної поведінки підприємства $€$ забезпечення достатнього рівня ліквідності активів та високої маневреності капіталу.

В рамках заданих інвестиційних стратегій підприємство обирає способи досягнення поставлених цілей, а) концентруючи свою інвестиційну активність в одній галузі шляхом удосконалення продукту або розвитку ринку; б) диверсифрікуючи власний інвестиційний порторель за стратегічними зонами господарювання для освоєння нових ринків збуту; в) інтегруючись із своїми контрагентами шляхом придбання корпоративних прав та власності для зростання масштабів ведення бізнесу та укріплення власних позицій на ринку.

Цілеорієнтованість інвестиційної стратегії виражає інтереси власників (інвесторів) підприємства та визначає вектор управлінського впливу на інвестиційну діяльність з точки зору есрективності та відтворюваності процесу інвестування. Вибір конкретних фрорм, методів та інструментів реалізації інвестиційної діяльності підприємства залежить від встановленого пріоритету у цілепокладанні, який може стосуватися як обслуговування поточних потреб операційної діяльності, так і стимулювання економічного зростання бізнесу та встановлення ринкового домінування підприємства.

Отже, такими цільовими орієнтирами фрормування інвестиційної стратегії підприємства $\epsilon[4 ; 8 ; 11]:$

- отримання додаткового інвестиційного доходу від інвестиційних операцій для поповнення обігового капіталу підприємства;

- підвищення ефективності операційної діяльності підприємства за рахунок комплексу технологічних та організаційних новацій;

- зростання ринкової вартості бізнесу для примноження інвестиційної цінності підприємства в перспективі; 
- масштабування бізнесу за рахунок розширення виробництва або диверсифрікації напрямків діяльності підприємства;

- створення нових підприємств шляхом злиття або поглинання.

Відповідно до ссрормованих стратегічних цілей і в межах поточних фрінансових можливостей підприємства здійснюється тактичне управління інвестиційною діяльністю [5, с. 141]. В рамках такого управління відбувається деталізація інвестиційної стратегії за етапами її реалізації, часове і просторове узгодження управлінських рішень, конкретизація фрорм і методів досягнення поставлених цілей.

Загалом, тактика управління інвестиційною діяльністю як управлінський процес передбачає органічну взаємодію двох складових:

а) процедурної складової, яка декларується у положеннях інвестиційної політики підприємства та регламентує зміст і послідовність виконання управлінських дій на отримання бажаного ефекту від інвестування;

b) результативної складової, яка розкривається через формування набору конкретних інвестиційних активів, визначених потребами стратегічного розвитку підприємства, та розподілу інвестованого капіталу між ними в пропорціях, здатних забезпечити заданий рівень дохідності, ліквідності та ризику інвестиційного порторелю.

Таким чином, інвестиційна політика визначає як саме приймаються ефективні інвестиційні рішення, щоб досягти очікуваних результатів, тоді як інвестиційний порторель демонструє практичну апробацію існуючих керівних засад і принципів інвестиційної політики в конкретних умовах інвестування.

Інвестиційна політика безпосередньо проявляється через систему правил, принципів та підходів до розробки управлінських рішень, дотримання яких забезпечує вигідне розміщення та використання інвестиційного капіталу відповідно до стратегічних цілей розвитку підприємства. Вона реалізується в рамках існуючої моделі управління підприємством та підпорядковується його довгостроковим інвестиційним цілям. Враховуючи це, інвестиційна політика виступає своєрідною «оболонкою», яка, з однієї сторони, транслює стратегічні наміри підприємства, a, з іншої, - визначає межі застосування тактичних інструментів управління інвестиційною діяльністю. По сутті, інвестиційна політика перетворює розроблену стратегію на відкриту та детальну декларацію основних напрямків інвестиційної діяльності підприємства, форм та методів її реалізації [11, с. 24].
Інвестиційна політика повинна відповідати характеру і масштабам діяльності підприємства, бути задокументованою, а також доступною для інвесторів і відповідальних виконавців [7, с. 86]. Попри те, що інвестиційна політика уособлює усталені технології прийняття управлінських інвестиційних рішень, іiї положення мають бути адаптованими до умов зовнішнього інвестиційного середовища та систематично коригуватися у відповідь на зміну інвестиційних цілей.

Інвестиційна діяльність завжди орієнтована на майбутній результат, ймовірність досягнення якого обумовлюється волативністю бізнес-середовища та поведінкою усіх учасників інвестиційного процесу. Невизначеність умов інвестування виступає джерелом генерації численних загроз, які здатні змінити очікувані результати та спровокувати непередбачувані втрати і збитки в результаті матеріалізації інвестиційних ризиків.

Враховуючи стратегічні цілі інвестиційної діяльності та готовність прийняти ризики, підприємство може реалізовувати консервативний, агресивний або компромісний тип інвестиційної політики [1, с. 174].

Реалізація консервативної моделі управління інвестиційною діяльністю відображає прагнення підприємства ухилятися від ризиків шляхом вибору надійних об'єктів вкладання капіталу, які дозволяють отримати хоч й незначний, проте передбачуваний i стабільний інвестиційний дохід. Агресивна інвестиційна політика націлена на свідоме прийняття ризику для отримання додаткових можливостей розвитку бізнесу. Вона передбачає цілеспрямоване вкладання капіталу у високоризикові об'єкти (інноваційні проєкти, бізнес-стартапи, цінні папери молодих перспективних компаній), комерціалізація яких дозволить максимізувати поточний інвестиційних дохід підприємства у найближчому періоді. Помірна (компромісна) інвестиційна політика передбачає розміщення капіталу в об'єкти, рівень сукупного ризику та прибутку за якими найбільшою мірою наближається до середньоринкових значень. Підприємство уникає вкладень у високоризикові об'єкти, одночасно відкидаючи низькодохідні інвестиційні проєкти та фрінансові інструменти, як такі, які не становлять для нього особливої інвестиційної цінності.

Стратегічна таргетованість інвестиційної політики в процесі тактичного управління забезпечується через фрормування інвестиційного портфрелю підприємства та опти- 
мізації його складу. Основним завданням порторельного інвестування $€$ забезпечення ефрективного розподілу капіталу між конкретними інвестиційними активами (реальними об'єктами і фрінансовими інструментами) відповідно до стратегічних орієнтирів інвестиційної діяльності підприємства. Так, якщо інвестиційна стратегія націлена на розширення бізнесу, то основні інвестиційні потоки направляються на реалізацію інвестиційних проєктів або в інші реальні активи, пов'язані із модернізацією виробництва, тоді як вкладення у фрінансові інструменти (корпоративні права, цінні папери, депозити) носять вторинний (похідний) характер, що проявляється, наприклад, у термінами і обсягами розміщення [2, с. 49]. Таке комбінування дозволяє створити особливу інвестиційну цінність порторелю, досягти якої неможливо при розміщенні коштів в окремо взятий актив, а саме: можливість оперативного маневрування інвестиційними ресурсами для забезпечення очікуваної норми дохідності та допустимого для інвестора рівня ризику при заданому обсязі фрінансування інвестиційної діяльності.

Для більшості підприємств при формуванні власного інвестиційного порторелю пріоритетними є саме об'єкти реального інвестування, адже саме вони відбивають потреби операційної діяльності в оновленні техніко-технологічної бази, нарощенні виробничих потужностей та впровадженні інновацій [9]. Разом 3 тим, фрункціональна спрямованість виробничої діяльності підприємств не виключає можливості та доцільності придбання фрінансових інструментів, особливо в цілях диверсифрікованого росту компанії.

Реалізація економічних інтересів інвестора можлива за рахунок використання збалансованого підходу до фрормування інвестиційного портфелю, за якого досягається найбільш повна відповідність його складу поставленим цілям за конкретних умов інвестування. Складність процесу фрормування такого інвестиційного порторелю полягає у наявності певних обмежень (бар'єрів), які визначають зміст управлінських рішень та впливають на можливості вибору об'єктів інвестування. До основних обмежень в процесі фрормування інвестиційного порторелю можна віднести ліквідність, фрактор часу, бюджет та законодавчі норми, які покликані контролювати і регулювати інвестиційні процеси (схема оподаткування інвестиційного доходу, дозвільні процедури, обмеження інвестиційних операцій 3 окремими активами тощо).
Ліквідність визначає потенційну здатність інвестиційного портфелю або частини його активів швидко перетворюватися у грошові кошти без істотних втрат їх вартості. Вимога підтримки необхідного рівня ліквідності портфелю обумовлена потребою забезпечити постійне відтворення інвестиційного процесу та виконати взяті зобов'язання перед партнерами. Ліквідність інвестиційного портфелю залежить від типу інвестиційних активів, термінів розміщення капіталу, а також організованості товарних та фрінансових ринків, їх кон'юнктурних коливань.

Склад активів інвестиційного порторелю обґрунтовується часовими орієнтирами досягнення стратегічних цілей інвестиційної діяльності підприємства. наявність таких чітких часових обмежень вимагає проведення синхронізації термінів реалізації реальних інвестиційних проєктів та/або періодів інвестування у фрінансові інструменти із конкретними етапами інвестиційної стратегії підприємства, а також узгодження тривалості та послідовності виконання окремих фрорм розміщення капіталу між собою.

При формуванні інвестиційного порторелю необхідно враховувати фрінансові можливості підприємства забезпечувати потреби у придбанні необхідних інвестиційних активів. Досить часто проблема лімітування бюджетних коштів при реалізації інвестиційної програми підприємства виникає як результат політики самофінансування, коли керівники не залучають зовнішні ресурси або через високі витрати на обслуговування боргових зобов'язань, або через можливі втрати контролю та послаблення участі в управлінні. В цьому контексті безпека вкладень витісняє комерційні мотиви інвестування та виключає можливість отримати додатковий приріст капіталу за рахунок обороту зовнішніх запозичень.

Обмеженість доступних для інвестування ресурсів вимагає встановлення пріоритетів у розміщенні капіталу та оптимізації його структури. Для таких цілей проводиться фрінансовий скоринг інвестиційних об'єктів, на підставі чого здійснюється їх ранжування за критерієм ефрективності інвестицій. Найчастіше на практиці в якості такого індикатора обираються внутрішня норма дохідності (IRR - Internal Rate of Return) або індекс рентабельності (PI - Profitability Index). На основі сорормованого рейтингу до реалізації приймаються ті інвестиційні рішення, які здатні забезпечити дохідність на рівні, не нижчому середньозваженої ціни капіталу, залученого в про- 
цес інвестування. Така оптимізація дозволяє есрективно розподілити ресурси між потенційно прибутковими активами та максимізувати сукупний приріст капіталу за наявних обмежень бюджету.

Розширення фрінансової спроможності інвестиційного портоелю потребує залучення додаткових джерел забезпечення інвестиційних операцій підприємства. Внутрішня мобілізація власного капіталу в інвестиційних цілях при цьому доповнюється надходженням зовнішнього фрінансування, що неминуче призводить до зміни структури інвестиційного капіталу, впливає на зростання його ціни та підвищення рівня фрінансових ризиків для інвесторів. Очевидним $€$ той фракт, що ефрективне управління інвестиційним порторелем потребує формування цільової структури капіталу на основі досягнення компромісу між його ризиком та дохідністю. Отже, інвестиційний порторель характеризуватися не лише оптимальним складом об'єктів інвестування, але й оптимальною структурою самих інвестиційних ресурсів. Основними завданнями, які можуть визначати дії інвестора при фрормуванні інвестиційного портореля є: 1) збереження балансу інвестиційних ресурсів шляхом залучення усіх можливих і доступних форм ресурсів із збереженням фрінансової стійкості підприємства; 2) фоормування пріоритетів між потенційними інвестиційними активами на основі вибору тих, які відповідають індивідуальним цілям інвестора та сприятимуть стратегічному розвитку підприємства [11].

Процес тактичного управління інвестиційною діяльністю знаходить своє логічне продовження у виконанні комплексу оперативних заходів, які безпосередньо пов'язані із практичною реалізацією сорормованого порторелю підприємства. Залежно від виду інвестиційних активів, включених до складу портоелю підприємства, оперативне управління інвестиційною діяльністю може здійснюватися у таких напрямках [3, с. 99]:

- реалізація та комерціалізація реальних інвестиційних проєктів;

- реструктуризація складу фрінансових інструментів інвестування.

Якщо управління реальними інвестиціями передбачає досягнення максимально можливої ефрективності реалізації кожного 3 обраних проєктів при заданих обмеженнях за часом, вартістю та якістю кінцевого продукту, то управління фрінансовими активами передбачає проведення періодичного оновлення окремих їх видів відповідно до початкових цільових параметрів дохідності, ліквідності та ризикоорієнтованості інвестиційного портфрелю. Незважаючи на різні технології обґрунтування управлінських рішень щодо розміщення капіталу в реальних та фрінансових активах, вказані напрямки взаємопов'язані за цілями та результатами інвестування.

Оперативне управління реальними інвестиціями здійснюється окремо за кожним проектом, який включено до складу інвестиційного порторелю підприємства, та передбачає реалізацію відібраних інвестиційних проектів у передбачені терміни з метою забезпечення своєчасного повернення вкладеного капіталу у вигляді чистого грошового потоку та отримання очікуваного інвестиційного прибутку [5, с. 142]. Слід зазначити, що саме часові обмеження проекту перебувають у фрокусі уваги та зусиль проект-менеджера, адже при порушенні термінів виконання окремих робіт (особливо критичних) існує висока ймовірність перевитрат ресурсів та зниження якості кінцевого продукту.

У процесі практичного освоєння реальних інвестицій проводиться:

1) формування календарного плану виконання проекту, який дозволяє отримати деталізований розклад його реалізації на основі структурної декомпозиції робіт та їх часової дифреренціації;

2) розробка капітального бюджету, який демонструє прогнозовані розміри надходжень і видатків за проектом, рух та приріст чистих грошових потоків, розкриває стратегію фрінансування інвестиційних та операційних потреб проекту;

3) складання календаря бюджету проекту, який фріксує конкретні дати освоєння коштів протягом усього періоду реалізації проекту та умови проведення відповідних платежів, що забезпечує узгодженість видатків із графріком постачань основних ресурсів, моніторинг критичних моментів виконання проекту та зниження пов'язаних із ними ризиків;

4) обґрунтування рішень про вихід проекту із інвестиційної програми підприємства. Такі рішення відносяться до числа найбільш складних процедур в управлінні інвестиційною діяльністю, оскільки викликані, як правило, недостатньою обґрунтованістю бізнесплану інвестиційного проекту, некоректним відбором об'єктів інвестування, істотними прорахунками у прогнозуванні фракторів зовнішнього середовища або навіть зміною планів інвестора чи появою нового альтернативного проектного рішення. Вихід підприєм- 
ства $з$ проекту може здійснюватися шляхом продажу корпоративних прав на його використання або закриття проекту та реалізації його активів за залишковою вартістю. Якщо є хоча $б$ незначна потенційна ймовірність поновити проект, то процес закриття повинен передбачити підготовку до майбутнього поновлення проектних робіт [8];

5) визначення напрямків реінвестування вивільнених коштів та заміна вилучених проектів новими, більш ефрективними.

Отже, проектне інвестування вимагає належної організації виконання запланованих робіт, централізації та координації дій відповідальних виконавців, забезпечення інорормаційно-аналітичної підтримки управлінських рішень, а також імплементації технологій інвестиційного конролінгу та аудиту якості проекту. Проведення контрольних заходів в критичних точках реалізації проекту дозволяє підтримати його цільову орієнтацію та своєчасно виявляти небажані відхилення, оперативно усувати джерела їх виникнення, проводити відповідні коригування складу інвестиційних активів 3 метою нормалізації і підвищення ефективності інвестиційної діяльності підприємства.

Оперативне управління фрінансовими інвестиціями передбачає підтримку цільової орієнтованості сорормованого порторелю підприємства та проведення реструктуризації його складу у відповідь на зміни умов інвестування. Ґрунтуючись на аналізі існуючих практик порторельного інвестування, розрізняють пасивний та активний підходи до управління інвестиційним порторелем підприємства.

Активне управління передбачає систематичну ревізію складу інвестиційного портфрелю та проведення своєчасної ротації окремих фрінансових інструментів у разі відхилення або невідповідності їх параметрів інвестиційним цілям підприємства. Швидка зміна складу порторелю вимагає безперервного моніторингу фрінансового ринку, аналізу поточної ситуації та прогнозування майбутніх котирувань цінних паперів. За такого управлінського підходу фрормування інвестиційного порторелю виступає як динамічний процес, який характеризується постійним переміщенням капіталу та оперативним оновленням інструментів, які його наповнюють - придбанням недооцінених активів з потенціалом довгострокового зростання їх вартості і продажем тих цінних паперів, які перестали задовольняти вимоги порторелю підприємства. На відмінну від активного трейдингу, пасивне управління передбачає тривале утримання сорормованого складу фрінансових інструментів в незмінному стані, незважаючи на поточні коливання їх ринкової ціни. Нівелювання поточної дохідності окремо взято тих порторельних інвестицій визначає стратегічну орієнтованість такого управління на забезпечення стабільного приросту вартості інвестиційного портсрелю.

Умовою ефективного застосування пасивної моделі управління $€$ наявність диверсифікованого порторелю фрінансових інструментів, практична реалізація якого знижує портфельний ризик за рахунок взаємного погашення збитків і прибутків у довготривалому періоді. Досягнення такого балансу у розподілі інвестиційного капіталу між обраними активами дозволяє гарантувати як бажану дохідність, так і рівень ризику, прийнятного для підприємства. Незважаючи на мінімальне втручання в інвестиційний процес при реалізації пасивної стратегії, поточна конорігурація інвестиційного порторелю переглядається 3 певною періодичністю для забезпечення контролю відповідності ії̈ структури визначеним цільовим параметрам інвестування.

Висновки. Забезпечити постійний контроль за реалізацією інноваційних ініціатив підприємства відповідно до обраної моделі інвестиційної поведінки можливо за рахунок системності та послідовності реалізації стратегічних, тактичних та оперативних рішень менеджменту підприємства. Такий підхід до організації інвестиційної діяльності покликаний забезпечити органічну єдність задекларованих стратегічних цілей, очікуваних результатів та засобів їх досягнення. Якщо стратегія інвестиційної діяльності декларує генеральний план поетапного досягнення поставлених довгострокових інвестиційних цілей, то тактика - фрормує конкретні методи та інструменти, практичне застосування яких перетворює обраний вектор інвестиційного розвитку підприємства в конкретних механізм досягнення бажаного ефректу від інвестування. Тоді як локальне адміністрування інвестиційного процесу дозволяє оперативно реагувати на виявлені відхилення, оцінювати джерела потенційних ризиків та попереджувати можливі втрати, регулювати рух грошових потоків та гарантувати ефеективність здійснених інвестицій.

Сучасні виклики і тенденції розвитку економіки визначають як ключову детермінанту розвитку підприємства його здатність до формування конкурентних переваг та масштабування бізнесу, досягнути яких без реальних 
інвестицій просто неможливо. Прийняття управлінських рішень 3 приводу доцільності інвестування в інноваційні технології вимагає ретельного аналітичного обґрунтування, саме тому подальші наукові дослідження мають стосуватися удосконалення методів бюджетування та фрінансового моделювання інвестиційних проектів.

\section{СПИСОК ВИКОРИСТАНИХ ДЖЕРЕЛ:}

1. Бушовська Л.Б. Управління інвестиційною діяльністю як важливий складник економічної безпеки підприємства. Економіка і суспільство. 2017. Вип. 11. С. 170-176. URL: https://economyandsociety.in.ua/journals/11_ ukr/28.pdf

2. Гайдай Г.Г. Інвестиційний портфель як важлива складова інвестиційної стратегії. Вісник Національного транспортного університету. 2019. Вип. 2(44). С. 48-55.

3. Голубєв Д.І. Етапи розробки інвестиційної політики підприємства. Економіка та держава. 2014. № 10. С. 97-99.

4. Гринько П.Л. Дослідження формування інвестиційної політики підприємств як важливого фрактору їх стратегічного розвитку. Технологический аудит и резервы производства. 2016. № 1/3 (27). С. 63-68.

5. Замятіна Н.В. Теоретико-методичні засади управління інвестиційною діяльністю підприємства. Фінансовий простір. 2013. № 3(11). С. 138-142.

6. Каут О.В., Дунайчук С.М. Аналіз типових інвестиційних стратегій промислових підприємств. Інвестиції: практика та досвід. 2018. № 7. С. 20-24.

7. Коритько Т.Ю., Крук О.М. Процес формування інвестиційної політики підприємства. Вісник Донбаської державної машинобудівної академії. 2016. № 3(39). С. 86-90.

8. Майорова Т.В. Інвестиційна діяльність : підручник. Київ : Центр учбової літератури, 2009. 472 с.

9. Сімкова Т.О., Байда О.К. Формування системи управління інвестиційною діяльністю підприємства. Ефрективна економіка. 2020. № 12. URL: http://www.economy.nayka.com.ua/pdf/12_2020/121.pdf

10. Скотнікова Л.П., Угрімова І.В. Роль інвестиційної стратегії у розвитку підприємства. Вісник Національного технічного університету «Харківський політехнічний інститут». 2018. № 19 (1295). С. 19-22.

11. Чорна М.В., Глухова С.В. Формування ефективної інвестиційної політики підприємства : монограсрія. Харків, 2010. 210 c.

\section{REFERENCES:}

1. Bushovska L.B. (2017) Upravlinnia investytsiinoiu diialnistiu yak vazhlyvyi skladnyk ekonomichnoi bezpeky pidpryiemstva [Management of investment activity as an important component of the economic security of the enterprise]. Ekonomika isuspilstvo - Economy and Society, 11, 170-176. Retrieved from: https://economyandsociety.in.ua/ journals/11_ukr/28.pdf (in Ukrainian)

2. Haidai H.H. (2019) Investytsiinyi portfel yak vazhlyva skladova investytsiinoi stratehii [Investment portfolio of the enterprise as an important component of investment strategy]. Visnyk Natsionalnoho transportnoho universytetu - The National Transport University Bulletin, 2(44), 48-55. (in Ukrainian)

3. Holubiev D.I. (2014) Etapy rozrobky investytsiinoi polityky pidpryiemstva [Stages of development of investment policy of the enterprise]. Ekonomika ta derzhava - Economy and state, 10, 97-99. (in Ukrainian)

4. Hrynko P.L. (2016) Doslidzhennia formuvannia investytsiinoi polityky pidpryiemstv yak vazhlyvoho faktoru yikh stratehichnoho rozvytku [Research of formation of enterprises investment policy of as an important factor of their strategic development]. Tekhnologicheskiy audit i rezervy proizvodstva - Technology Audit and Production Reserves, 1/3 (27), 63-68. (in Ukrainian)

5. Zamiatina N.V. (2013) Teoretyko-metodychni zasady upravlinnia investytsiinoiu diialnistiu pidpryiemstva [Theoretical and methodological principles of enterprise investment management]. Finansovyi prostir - Financial Space, 3(11), 138-142. (in Ukrainian)

6. Kaut O.V., \& Dunaichuk S.M. (2018) Analiz typovykh investytsiinykh stratehii promyslovykh pidpryiemstv [Analysis of typical investment strategies of industrial enterprises]. Investytsii: praktyka ta dosvid - Investments: practice and experience, 7, 20-24. (in Ukrainian)

7. Korytko T.Yu., \& Kruk O.M. (2016) Protses formuvannia investytsiinoi polityky pidpryiemstva [The process of forming the investment policy of the enterprise]. Visnyk Donbaskoi derzhavnoi mashynobudivnoi akademii - Bulletin of the Donbas State Engineering Academy, 3(39), 86-90. (in Ukrainian)

8. Maiorova T.V. Investytsiina diialnist [Investment activity]. pidruchnyk [textbook]. Kyiv: Tsentr uchbovoi literatury, 472 p. (in Ukrainian) 
9. Simkova T.O., \& Baida O.K. (2020) Formuvannia systemy upravlinnia investytsiinoiu diialnistiu pidpryiemstva [Formation of the enterprise investment activity management system]. Efektyvna ekonomika - Efficient economy, 12. Retrieved from: http://www.economy.nayka.com.ua/pdf/12_2020/121.pdf (in Ukrainian)

10. Skotnikova L.P., \& Uhrimova I.V. (2018) Rol investytsiinoi stratehii u rozvytku pidpryiemstva [The role of investment strategy in enterprise development].Visnyk Natsionalnoho tekhnichnoho universytetu «Kharkivskyi politekhnichnyi instytut» - Bulletin of the National Technical University «Kharkiv Polytechnic Institute», 19 (1295), 19-22. (in Ukrainian)

11. Chorna M.V., \& Hlukhova S.V. (2010) Formuvannia efektyvnoi investytsiinoi polityky pidpryiemstva [Formation of effective investment policy of the enterprise]: monohrafiia [a monograph]. Kharkiv, 210 p. (in Ukrainian) 